\title{
SPIRITIST BOUNDARY-WORK AND THE MORALITY OF MATERIALITY IN AFRO-CUBAN RELIGION
}

\author{
$\checkmark$ DIANA ESPIRITO SANTO \\ Institute of Social Sciences (ICS), University of Lisbon, Portugal
}

\begin{abstract}
This article explores the significance of notions of materiality in the practice of Cuban espiritismo and in the Afro-Cuban religious cults of santería and palo monte. In particular, it pursues an understanding of the kinds of relations that are seen to emerge between the practitioners of these cults and the spirits of the dead - relations produced through their varying interpretations and uses of 'matter', in which corresponding moral implications obtain. The author further examines the importance of 'things' and their absence through an ethnographic analysis of the radically diverging discourses on the nature of spirit mediumship among competing spiritist groups in Havana. At one end of the spectrum lies the highly syncretic practice of espiritismo cruzado (crossed spiritism), characterized by its cosmological and ritual inclusivity, while at the other end is the doctrine-based espiritismo cientifico, where a popular concept of science places stricter limits on what can be understood as legitimately 'spiritual'.
\end{abstract}

Key Words $\bullet$ Afro-Cuban religion $\bullet$ boundary-work $\bullet$ materiality morality $\bullet$ spiritism

\section{INTRODUCTION}

All groups, professional, religious, ethnic or cultural, tend to protect the boundaries of their activities and thus the autonomy and legitimacy of their knowledge or expertise. The sociologist Thomas F. Gieryn's (1983: 
781) analysis of the kind of ideological 'boundary-work' at stake among scientists is particularly revealing of the fact that very often these borders need to be actively sought and defended against other activities that do not belong inside them, in this case, non-scientific, intellectual, religious or technical ones. Coherence is, to some extent, a property of inclusion, or of inclusive discourse, which is defined at least in part via the processes of exclusion and their discourses of validation. In the anthropology of Afro-Brazilian religion, Hess $(1991,1994)$ has convincingly applied such notions to an understanding of the rhetorical relationships constructed between the various kinds of Afro-Brazilian, Catholic and spiritist traditions, as well as the sciences and parasciences, where their respective discourses of accreditation draw on appeals to scientific validity, orthodoxy, or religious purity. But while Brazil is an especially relevant arena in which to observe the explicit articulation of religious boundary-work - for the history of these movements is openly fraught with such attempts at dialectical self-definition - Afro-Cuban religion presents us with an equally powerful, albeit more subtle, example of such processes. In this article, I wish to build on and extend Hess's appropriation of Gieryn's notion by proposing the centrality of concepts of 'matter' to the kinds of boundary-work that are observable among Afro-Cuban religious specialists and adepts, as well as between spirit mediums of differing practice traditions. In contrast to Brazil, many of the more popular forms of Afro-Cuban religiosity are experienced as continuous and overlapping, rather than as overtly discrete or antagonistic, which means that boundary-work here must be seen to occur within an internal dimension of a logic that is, by and large, common to all practitioners. I will argue that 'matter' is one of the important bases of differentiation in this cosmos, and that, moreover, it is thought about and experienced as a highly moralized aspect of religious sociality. In this ethnographic context, 'materiality' does not just describe the physical or concrete: its categorical interpretation and use in ritual practice operates in the conscious making and unmaking of the legitimately spiritual (or immaterial).

In contemporary Afro-Cuban religion, icons, artefacts, spirit representations, sacrificial offerings and other ritual objects or consumables do not just embody or represent; rather, they engender a complex set of cosmological and social relations, expectations and effects that go well beyond their production and use at any one given moment. In Cuba, matter matters, not because it is symbolic or expressive of (and thus, subordinate to) a transcendent spiritual world, but because for many religious people it is vital for the achievement and manipulation of the spirit world's presence in the physical world: among other things, as a means of miming the otherworldly into being (Taussig, 1993). Indeed, the use of the word 'material' to describe a practice, object, place, spirit, or person, ordinarily occurs, and thus can only be understood, in its relation to the 
term 'espiritual'. 'Material', here, would signify religious practices, ritual occasions, or entities that rely significantly on material 'things', such as those described earlier; whereas 'espiritual', while fraught with ambiguity, would refer to the effectively 'immaterial' element of such 'things', a kind of pure state, which in principle excludes the potential corruptibility of earthly 'things'. However, it is not just that one presupposes the other, especially in a religious universe where the spiritual is typically particularized and rendered meaningful through its encounter with the material, but also that it is only of consequence in an Afro-Cuban religious context to denominate something as material since it also denotes its capacity to be spiritual. Indeed, for most Afro-Cuban religious practitioners, anything that is or becomes 'material' and/or 'spiritual' is not regarded as static, homogenous or unproblematic: to evoke such terms is to make an implicit or explicit value or moral judgement. That AfroCuban religious followers tend to reinforce, negate or negotiate this opposition in ways that often depend on their own religious biographies, interests and moral standpoints indicates that 'matter' necessarily comprises a key object of ethnographic inquiry, one that is particularly revealing of the kinds of processes of differentiation that occur within a tight-knit and cosmologically interpenetrative, as well as morally laden, religious environment.

In the rest of this article, I will explore such processes from the perspective of two diverging practices of spirit mediumship in Cuba espiritismo cruzado ('crossed' spiritism) and espiritismo cientifico (scientific spiritism) - the first of which is immersed within the Afro-Cuban religious sphere, and the second of which follows a more doctrinal form of practice, distinguishing itself, among other things, as a scientific religion.

Among spirit mediums of both kinds, certain discourses on the nature of the mediumship project are essential for understanding how and what limits are placed on what is legitimately 'spiritual' work, and what is considered too 'material'. On the one hand, the visible and invisible worlds for spirit mediums are theoretically so seamless that to distinguish one's own thoughts - and the causes of one's actions - from those of one's spirits, is the very essence of mediumistic and spiritual development. Thus, it is a division predicated on matter, where a certain amount of phenomenological entanglement is vital for the definition of spiritual knowledge itself. On the other hand, it is well known that lo espiritual is not equivalent to lo material, particularly when it comes to ritual approaches: these are two domains where not just distinct spiritual entities may exist and co-exist, but where different parameters of intentionality and behaviour may apply. In particular, notions of spiritual potency and power, in relation to degrees of materiality, are critically important in understanding how espiritistas cruzados locate their practice in the Afro-Cuban religious spectrum. 
Concepts of science and rationality are of particular relevance to the espiritismo cientifico groups, who clearly oppose what is deemed 'scientific' and spiritually genuine to what is 'primitive' in the cruzados because of what they perceive to be the latter's embrace of lo material. Indeed, for the most part the cientificos work to undo the effects of a spirit's materialization, or attachment to matter, seen as ultimately responsible for its backwardness and ignorance, often to the detriment of the mediums it possesses. While cruzado mediums generally construct an interchange with their spirits through 'things', a cientifico believes that this interchange should be ultimately ideological or psychological in nature, where the only truly moral final objective is the absence of 'things', particularly ritual paraphernalia. Echoing a now dated Cuban revolutionary rhetoric, these spiritists tend to stereotype Afro-Cuban religions as superstitious and exploitative, thus denying them ultimate credibility. Among other factors, this attitude must arguably be understood in the context of a long and somewhat problematic history of public and scholarly approaches to Afro-Cuban religious traditions that has tended to place witchcraft next to backwardness, which, while nurtured by the early works of Fernando Ortiz (1995[1906]) on the so-called 'African wizards' (negros brujos), continues to be used in both popular and academic parlance.

The point I want to make in this article is not just whether a 'sustained project of immateriality' (Engelke, 2005: 199) is possible or deemed viable (and how) by certain spiritists or practitioners of Afro-Cuban religions. It is that such concerns are often made sense of and articulated via their alternatives and/or opposites, in which the moral economy of broader notions, such as spirit, matter, science, knowledge and ignorance, come to the fore.

\section{SPIRITS, SAINTS AND DEITIES IN CUBA}

Current Cuban spiritist practices draw from a variety of rich traditions. In an important sense, they draw from a European Kardecist ${ }^{1}$ spiritism that penetrated the island's religious imaginary in the middle of the 19th century. As the product of a predominantly bourgeois dissatisfaction with Christian religious hierarchies, combined with a certain Victorian faith in the promise of science to somehow categorize and explain the workings of the supernatural, the spiritist doctrine found an easy home among Cuba's disenfranchised and independence-minded creole middle classes (Brandon, 1997[1993]). It was assumed that, with the aid of spirit guides, a gifted medium could communicate with disencarnated beings, preferably enlightened ones, as well as helping the more ignorant or lowly ones. Castellanos and Castellanos (1992: 192) argue that among a population that already believed that the soul survives death, these ideas were immediately popular. An espiritismo cientifico was thus born under 
the rubric of a 'modern' approach to religious experience, and versions of it are practised to this day, namely, in those temples that survived the destabilizing effect of the Revolution's first decades on all institutionalized religious structures (Ayorinde, 2004).

But in the popular sphere, spiritism underwent a series of crucial transformations, significantly adapting to existing and emerging indigenous, folk Catholic and Afro-Cuban cosmological frames. It became notably syncretic in appearance, where its rites of possession, called misas espirituales (spiritual masses), manifested elements of all these traditions, simultaneously reintegrated and reworked, from Catholic prayers and crosses, to African chants and 'Indian' spirits. As Brandon (1997[1993]) notes, the spirit guides became as diverse as Cubans themselves, embodying the 'images of Cuban ethnic, racial and professional groups' (p. 87): the new spirits of an espiritismo cruzado. Essentially, it was with two strong Afro-Cuban traditions that espiritismo was to form an association: first, with regla de ocha (more commonly known as santería) and, second, with regla de palo, or palo monte. As Palmié (2002: 165) has argued, the spiritist medium constituted a new kind of communicational 'ritual technology' that linked the formerly unavailable spirits of the recently deceased within these cults, reuniting African ancestors with their descendants in the New World. From these two practices, espiritismo acquired a pragmatic and instrumental flavour, with the spirits now coming down to cleanse and advise their earthly counterparts in lively rituals of possession; tobacco and sugar-cane liquor became the spirits' cleansing agents, brought forward from a past of colonial slave labour, but the songs now honoured the gods of unseen Yoruba and Congo lands.

Santería, a composite of religious traditions of West African origin, is probably Cuba's most famous Afro-Cuban religious practice; it worships the orichas, historically associated with and now known simply as santos (saints), entities described as demi-gods or divine ancestors that possess exceptional power or aché due to their extraordinary lives and deaths (Bolívar, 1990; Brown, 2003; Lachatañaré, 2001). The basis of this practice is people's unique relationship to their santo, to whom they are initiated, most commonly if this need is expressed by the santo itself, during oracular consultation. After what is usually an elaborate and costly ceremony, initiates must observe strict rules and taboos in order to achieve maximum prosperity and health, but can also legitimately coerce their santo into granting favours. Known as a 'material' religion by its practitioners, not least because it is seen to 'resolve' problems of a distinctly material and economic kind, santería regularly involves possession ceremonies and ritual sacrifices and offerings; far from being trivial mediators, 'things' are constitutive of these very relations. The dead here are of particular importance. In ocha cosmology, not only were the orichas once spirits of the dead themselves, but it is fundamental that one's 
ancestors and guides (collectively known as the eggun) be materially taken care of and consulted before any ritual step is taken.

In palo monte, by contrast, the physical rather than spiritual dead take centre stage. A religious tradition associated with the Bantu-speaking groups of the Congo Basin (Bolivar and Diaz de Villegas, 1998; Figarola, 2006; Fuentes Guerra and Gomez, 1996), in Cuba palo monte is an umbrella term that designates a group of ritual practices whose core activity centres on the working of a nganga, a metal or wooden receptacle that contains a particular spirit with whom a pact has been made. Ngangas are, in effect, models of the cosmos, or miniature worlds, where the presence of nature is imperative to this recreation: apart from sticks, plants, metals and other substances, a nganga must also contain the bones of the muerto (the spirit) that is bound to it - sometimes called perro nganga (nganga dog) - that obeys the palero in exchange for material forms of reciprocity, such as animal blood. Often visually striking, ngangas embody in the most visceral way the social liminality of the spirits they contain. In Havana, paleros are simply known as brujos (sorcerers), a term that, while denoting a degree of deference, also carries with it considerable suspicion and prejudice, for it is thought that paleros possess the ritual tools with which to do excessive bad as well as excessive good, due to the deeply 'materialized' nature of their perro nganga.

Santería and palo monte are prime candidates for a study of religious boundary-work. Indeed, Palmié has dedicated a good portion of his Wizards and Scientists (2002) to unravelling the historical dimension of the relationship between ocha and palo, which he claims 'may have been accelerated by the catalytic effect of spiritism, easing the intellectual integration of heterogenous conceptions about the dead in the two major Afro-Cuban traditions' (p. 192). Palo and ocha, he argues, 'stand to each other like religion and magic, expressive and instrumental forms of human-divine interaction', where it seems that neither one 'could have evolved to their present phenomenology and moralized positions along a spectrum of differentiated ritual idioms without the presence of the other within the same social framework' (p. 193). But my contention is that the boundary-work between both of these traditions cannot successfully be understood in isolation. While it is beyond the scope of this article to discuss the specifics of this relationship much further, I wish to pick up on the importance of the contemporary role of spiritists, as practitioners of arguably Cuba's most widespread ritual and religious cult (Bolivar and Orozco, 1998: 288) in articulating these moral distinctions. And nowhere is this clearer than in the moral dilemma that spiritists themselves face. 


\section{THE SPIRITIST DILEMMA}

In Cuban spiritism, there is a sense in which all spirits conform to a degree of 'purification', through which they ultimately stand in a relational position to one another. But, as for Kardec, for espiritistas this relational stance is by no means clearcut, since not only are different spirits potentially 'good' for different things, but the interactive medium-spirit project itself allows for considerable human agency in a spirit's individual 'evolutionary' trajectory. While, for Kardec, spirits may range in infinite gradations from 'imperfect' and 'good' to 'pure' according to their intellectual and moral advances, in Cuban espiritismo, to abstract these spiritual categories from a material context makes them redundant as this moral and intellectual knowledge is always for something. Significantly, this criterion often turns on notions of 'materialization' and 'earthliness' as desirable or undesirable conditions of spirit, which itself speaks to the tenuous balance that must be sought between the usefulness of knowledgeable spirits, and those that may be perhaps too knowledgeable to have any tangible material influence. In theory, spiritists are faced with a dilemma. On the one hand, mediums must cultivate a reciprocal relationship with a spirit who will need to manifest in order to convey knowledge, to materialize, so to speak. On the other hand, they must also seek to elevate this spirit so as to increase its clarity (claridad) and efficacy in the generation and retrieval of quality information. Where the latter mode would be espiritismo cientifico's priority, for most espiritistas cruzados a spirit's inherent 'materialization' and ways-of-the-world are exactly what are seen as valuable. For example, it is common for a medium to acknowledge the various advantages of having spirits that were brujos (witches, or paleros), santeros, priests of Ifá (ocha's divination cult), or even espiritistas in life; as entities who were once 'connected' to a religious domain, these spirits not only come with an innate potency as protections (protecciones) in the realms of the everyday lucha (fight, or battle) or even spiritual warfare, but they are naturally equipped to advise and direct the actions that must be taken by the individual in order to win these battles. However, the cultivation of these spirits is also a moral choice and, as such, has dividends and consequences.

What I have been calling the 'spiritist dilemma' parallels, in an important way, Engelke's (2007) notion of the 'problem of presence', expounded in detail in his monograph on a Shona-speaking congregation of Masowe Apostolics in Zimbabwe. For the Masowe weChishanu, texts, such as the Bible, are dangerous: 'They deaden faith; they take the spirit out of things; they are, quite literally, physical obstacles' (p. 7). Knowledge, or (roughly) mutemo, as Engelke explains, is achieved mainly through the production and maintenance of an 'immaterial' sort of faith, which is the opposite of what he calls 'thingification', 'the process through which the object is divested of immateriality' (p. 27). Among the Apostolics, 
some things, such as sound (particularly the voice) are more 'immaterial' than others and are conceived to constitute the proper and desirable channel for God's presence. However, if the 'problem of presence is a problem of representation and authorization' (p. 11), then the Apostolics set themselves a far from unambiguous task, as unsettling substances such as 'holy honey' (p. 226) clearly indicate. The fact that some substances, such as the muteuro (objects that cleanse the body of spiritual impurity - pebbles, for example), are significant and others are not is also telling: achieving God's presence immaterially is a carefully crafted and often temptation-laden endeavour, for matter is also fraught with temptation. Many similarities can be drawn between both kinds of 'problems' - those of the Cuban spiritists and those of the Masowe Apostolics. For spiritists, too - even the cruzados - matter risks 'deadening' the spirit through over-densification. Cientificos are particularly wary of the 'thingification' of spirits, whose trajectory of legitimate spirituality is hindered via this objectification. But if, for Engelke, the 'problem of presence' relates to 'how a religious subject defines and claims to construct a relationship with the divine through the investment of authority and meaning in certain words, actions, and objects' (p. 9), the problem in espiritismo relates to the production of the divine (or spirits) through words, actions and objects, all of which construct selves in the process. Thus, it is an essentially cosmogonical, rather than representational process.

To see how spiritists morally understand themselves in relation to Afro-Cuban religious practices, we need to understand what kinds of muertos and persons are produced by these distinct moral spaces of interaction.

\section{MORALITY AND THE SPECTRUM OF AFRO-CUBAN RELIGIOUS MATERIALITY}

'With regard to spiritism', said Jesus, an elderly spiritist medium and palero I interviewed on various occasions:

Those of us who practise it, do it with faith and love. I must be certain within myself of what I have lived. Just as you see these glasses of water, transparent and clean, a spiritist should be exactly the same way.

Jesus's speech, which evokes the metaphors of cleanliness and transparency in a description of 'good' spiritism, is typical of espiritistas who are regularly exposed to, and even practise, other forms of Afro-Cuban religion. That he needs to have a clear conscience is, in effect, what Jesus is telling me here; that he needs to be motivated by faith and love, rather than vengeance or greed, is also what he seems to be suggesting. The way of the 'pure' spiritist is a 'camino de azucena, de agua' (the path of 
lilies, of water), said another of my friends and informants, Arturo, whose nganga is one of the largest and most elaborate I encountered, something that makes his own negotiation of the two extremes, represented by his endeavours as both a spiritist and a palero, extremely clear. 'What usually occurs in spiritism', he continued, 'is that one deals with a troublesome spirit by conversing with and convincing it of the error of its ways - by bringing it to a convencimiento (an understanding), as people say'. In palo, however, there is no possible compromise: 'se quita el muerto y ya' (you just get rid of it), by which he means through immediate and unmerciful witchcraft. However, as Arturo was keen to stress, he is not an ordinary palero:

When you decide to construct a nganga they tell you that you must acquire a stupid muerto, an illiterate, so that you can control him easily. In my case it wasn't like that. Mine had to be brilliant, illustrious, precisely because I didn't want to take him in order to do evil (daño).

As with many other paleros I met, Jesus and Arturo pre-emptively defended themselves to me during the interviews by claiming an absolute personal refusal to engage in the 'dirty work' so characteristic of a palero's popular image. And they did so, more specifically, by expressing a dedication to the more 'spiritual' aspects of their practice, especially their medium work - seen to be bereft of the heavily 'material' aspect of their palo work. Not only was the primitivism of others' nganga spirits contrasted unfavourably with the quality of their own, but the 'material' component of their engagement with money was also denied, both claiming indifference to financial incentives when determining what obras (witchcraft) they chose to perform. In a contemporary urban environment in which Afro-Cuban religious experts have become infamous for their commercialization and exploitative techniques - they have become 'metalizados' (literally, metallized) as one of my informants said - this is perhaps unsurprising (Argyriadis, 2005; Hagedorn, 2001). But most of all, these statements alert us to the implications of the concept of 'matter' in this ethnographic setting. 'Lo mio es lo espiritual' (my path is spiritual), I have heard many paleros and santeros admit - particularly those who have been mediums for a long time - regardless of their dedication to their religious initiations, clearly indicating on which side of the moral order they stand. These qualifications are highly telling not just of the kinds of narratives engendered in order to make sense of coexisting ritual roles, but of the kinds of discourses that circulate in a more general environment of Afro-Cuban religious practice. That good and evil, moral and immoral, are categories that are in many contexts implicitly or explicitly referred to as dichotomous alternatives, naturally embedded within the potentialities of these practices, tells us that we are dealing with a frame of reference that is understood and transferable in these 
same contexts. In the following paragraphs, I will explain how the differences in this shared framework are produced through 'matter'.

Among santeros, paleros and espiritistas, the crucial means of 'materializing' the spirit is through food, which is thought to increase the spirit's ability to protect or obey. As occurs more generally in the fabric of lived family and social relationships, food is one of the primary ways by which Cubans generate and express warmth, gratitude and solidarity with the spirit world. It both stands as a symbol for these feelings and as an instrument in and of itself, for it is thought that spiritual entities can and do eat, somehow. In santería houses it is normal to lay out food for the dead, usually as part of a religious rite, where the eggun must always eat and drink before anyone else. But there are also darker connotations to the idea of feeding. Food is indeed such a potent vehicle for establishing and manipulating the spirit-human dynamic that paleros often use it to distract their victim's spirit guides so as to more easily pierce his or her spiritual 'space' and inflict the intended damage or death. Montalbito, a santero, palero and spiritist friend once explained this, using me as a hypothetical victim:

This is a fight, but a fight with tricks, a dirty fight, because I entertain your guardian angel, I give it food, and I also give food to your protecciónes and, while they are distracted, I take advantage of the situation to find a way in. Whatever it is that I send [by which he means the spirit tasked with destroying me] takes advantage of the moment in which Diana's spirits are absent, when there is empty space. It's like a baseball game. A hitter will strike towards where the field is empty.

It is the blood of sacrifice that begins to sort out the more 'materialized' muertos from the lesser ones. While spiritists know that once a person becomes spiritually developed, they make an implicit commitment to the spirit world, they also know that the extent to which this is an explicitly 'material' commitment has ramifications. Jesus, for example, told me:

One of the ladies that recently came to see me is very spiritual, but she doesn't attend to her 'things' [i.e. materially, with animal blood]. She tells me - I'm not crippled, I'm not ugly, there's nothing wrong with me, so why do none of my marriages last? I tell her that it could be that while before she attended to her religious 'things' (cosas), she now does not, and that this harms her. I will tell you something: once you get yourself initiated in the spiritual field, do your best to keep yourself there.

Jesus's statement is less of a warning than an articulation of a simple formula: the decision to engage with a spirit via a relationship constructed through sacrificial offerings creates obligations, for one is creating a particular sort of spirit in the process. While the palero's nganga personifies the most extreme end of such contracts, precisely because its power 
- gained through materiality - can so easily lead its practitioner astray or even consume him or her, there are in fact many possible forms of similar engagement between the santero and the spiritist. In essence, most religiosos face the task of deciding to what extent they will materialize their muertos, a decision that must balance material power with its possible consequences. A case in point is that even the innocuous spirit representations - the dolls, icons or statuettes that people dress, adorn and display as workable images of their spirits - can be laced with consecrated material substances that confer on these objects special powers, especially if they are given blood. These 'charges' (cargas) are sometimes sewn into the object, and are perceived to be able to bring the muertos to a different level of material existence, and thus efficacy.

The moral order implicit in the categorization of spirits becomes particularly evident in palo, as I have suggested. That paleros are known to value spirits whose lives and deaths have been characterized by violence or insanity is suggestive of the idea that moral vulnerability is a fundamental trope in understanding a perro's efficiency. Paleros are often thought to manipulate this ignorance to their own ends for, as the saying goes: 'arriba de la nganga, no hay sentimiento' (where the nganga is concerned, there is no room for sentiment) and, just like their perros, being recognized as a palero can entail being regarded as naturally unvirtuous. Indeed, spiritists who work merely lo espiritual often criticize the palero's endeavours precisely by implying a contradiction of some of the very basics of the spiritist moral project. Misas espirituales are not carried out to one's nganga spirit, for instance, because the aim is not to give it 'knowledge' or 'light'; instead, the spirit is darkened through the ongoing process of its enchainment to matter, which through time is designed to increase its power. The opposition between good and evil spirits engendered by palo is mirrored, at its crudest, in the distinction between the nganga Cristiana (Christian nganga) and the nganga Judia (Jewish nganga). While the former always holds within it a crucifix as a symbol of its commitment to Christian 'good', the latter lacks such an item, allowing, in its stead, the forces of evil to enter it and add to its destructive efficacy. The nganga Judia exemplifies the most unacceptable kind of selfish individualism, manifest in a kind of treaty with the devil, as well as constituting the object of the worst kind of religious paranoia - that which can kill quickly and unreflexively. While it is not uncommon, in fact, for a palero to have both, if only for an emergency, there is no doubt that the so-called palo Judio spins in and of itself a kind of enticing moral mythology, to which all other forms of religiosity find themselves in relation. Stories of 'evil-doing' paleros Judios eventually losing their houses, alienating their families and meeting with ghastly deaths are plentiful in Afro-Cuban religious circles. But having nevertheless to answer to such moral qualms, the spiritist and santero's 
solution has been articulated in an interesting way: the nganga (or prenda) espiritual. While not initiated in palo, many santeros and espiritistas respond by possessing what is perceived as a less materialized nganga, one that is, significantly, worked by a more evolved spirit. In this nganga there resides no enslaved spirit, nor does it, in most cases, receive blood. It is, rather, a symbolic or virtual instrument that takes life in the spiritual world rather than the material one. The spiritist is, in this sense, exempt not only from potential accusations of witchcraft, but excused from being seen to contribute to a spiritual entity's backwardness through its material imprisonment.

What I have attempted to show here is that spirit mediums inserted in an Afro-Cuban milieu must often walk a fine line not only with regard to the kinds of relationships of 'matter' they establish with their spirits, but with the consequences of these relations for the projection of their image to others. In the final section, I will examine the rhetoric of spiritists who reject the importance of matter altogether in the spiritist project.

\section{IGNORANCE, KNOWLEDGE AND THE SCIENCE OF MEDIUMSHIP}

The small number of self-denominated espiritismo cientifico groups in Havana take on board, in the most literal way, Kardec's assertion that spiritism is science, philosophy and morality. An emphasis on doctrinal tradition and on the importance of careful study is one of the central facets of these groups, essential not just to their projection as educated and bona-fide spiritists - and thus, to the viability of their spiritual philosophy - but to the creation of a boundary of legitimacy, which, in most circumstances, contrasts their spiritual approaches with those of the more 'syncretic' and 'African' lines, thought to be unnecessarily, and sometimes immorally, materialistic. 'There is spiritism and then there is animism', said a scientific spiritist to me once in a class dedicated to the subject, notably where later he compared the gravity of preparing oneself for mediumship with that of medicine: 'we have a duty to moralize ourselves.' The difference between a 'clean', and thus real, form of spiritism and a reckless 'mediunísmo' (derogatory way of referring to mediumship), according to him and to many others I interviewed, is morality. And it is, among other things, a morality predicated on the absence of 'matter', interpreted both through the use of ritual objects and an uncalled-for dramaticality during spirit incorporation sessions. One of the most prevalent ideas among these groups is that, while many individuals have the right faculties, not all are morally equipped to use them for many mediums are as ignorant as their spirits - where ignorance is defined as intellectual and ethical paucity. In what follows, I take my data on one such group, the government-backed Consejo Supremo Nacional 
Espiritista de Cuba (Cuban National Council of Spiritism), to show how a rejection of the importance of 'matter' in the practice of spirit mediumship constitutes one of the primary axes upon which the borders of an espiritismo cientifico are delineated. More specifically, I will focus on the leader's own discourse and religious biography, both of which are clearly punctuated with political overtones that further highlight some of the differences between these domains.

Consider the following extract, quoted from an institutional statement of purpose (c. 2006, my translation from Spanish) written by the charismatic leader of the Consejo Supremo, Alfredo Durán Arias:

If Kardec defined spiritism as the science which investigates the nature, origin, and destiny of the spirits and their relation with man, conceding to it a scientific, philosophical, and moral character, with a doctrinal body and basic precepts that afford it a unique identity, separate from any other religious cult, then we may ask ourselves: how can we speak of espiritismo cruzado if our teachings reject rituals, altars, witchcraft, miracle-working, fanaticism, the consumption and use of material substances like alcohol, tobacco, and other drugs; practices typical of African and indigenous cults which many have tried to relate to our doctrine? None of these and other denominations can resist the slightest analysis of reason, logic, and serious study that emerge from the codification that constitutes the basis of our writings.

In this explicit critique of 'African' and 'indigenous' practices, Durán reflects a common assumption in scientific spiritist circles: that all material forms of religious engagement are necessarily more backward and primitive, for they fundamentally misconstrue the genuine purpose of spiritism. It is immediately tempting to see in this rhetorical boundary-work a process reminiscent of what Brown (1986) has argued characterizes the emergence of a 'pure' Umbanda in Brazil - that is, a move towards the 'Europeanization' or 'whiteification' of the practice of spirit communication, stripped of its African influences. It is undeniable that such appeals to reason, science and even 'cleanliness' - appeals which both cruzados and cientificos are guilty of - have a disquieting role in the historical production of metaphors of 'contagion' in relation to Afro-Cuban religion, particularly in the 19th and early 20th centuries, and therefore also of 'containment'. As Wirtz (2009) has convincingly argued in a recent article on the power of ritual waste, enduring official and elite squeamishness towards popular religious practices derives in great part 'from long-standing racist notions that modernity and Afro-Cuban culture are incompatible' (p. 486). Thus, while in a purely ethnographic sense, Durán's statement goes to the core of what kinds of spirits are seen to be produced in more 'materialized' settings, which, in contrast to 'scientific' ones, tend to be of a 'lowly' sort, we would be foolish not to observe that it may also reflect a broader Cuban history of race-based discourses, noted, among others, by Bronfman (2004). 
However, as salient as racial politics may be as a dimension of the moralization of 'matter' proper in Cuba, it is also true that, on the ground, scientific spiritists see themselves as the very opposite of racist in their professed beliefs, as Durán alludes to in the following quote (which, in the light of the Revolution's own dissolution of 'race' as a question, does not cease to be of special interest, needless to say). Rather, spiritual freedom, for Durán, must ultimately come with a freedom from material constraints and dependencies - even identities, racial or otherwise. Espiritistas, more than anyone, have a duty to educate their spirits in this way, if by nothing else than their own conduct, where the only legitimate form of differentiation is the quality of the spirit itself, stripped of its materiality. For Durán, this civic duty to the spirit world is so imperative to good mediumship that he seems to define mediumship itself as a form of moral behaviour, where good mediumship ideally culminates in the construction of a non-exploitative and equality-based society. The existence of such morally 'sick' societies as the United States and other 'imperialist' nations, Durán insisted to me more than once, is unquestionable evidence that man too readily lends himself as a puppet to the wills of lowly, avaricious spirits. Here, as I have suggested, spiritism takes on a markedly political tone. Spirits of knowledge, he says, inspire us to work towards an egalitarian and humane society. Duran envisages the mediumship project as a kind of creative cycle of progress based on action where, through our hard work, communitarian values and just behaviour, 'se nos multiplica la mediunidad' ('our mediumship is multiplied'). Knowledge, in this sense, is materialized in pursuit of a greater good - la humanidad (humanity) - rather than for individual benefit, where its exact source becomes largely arbitrary. Because spirits are drawn to people by affinity, those that are attracted by noble endeavours will inevitably be spirits of 'light'. Afro-Cuban religions, on the other hand, including less 'scientific' spiritists, will succeed in rallying only ignorant entities, whose knowledge is limited to the exploitative and superstitious religious activities they performed in life. Highly partial in inclination, then, Durán's interpretation of spiritism is pitted against what he sees as the 'adoration' of particular individualized spirits and their representations, which he calls 'idolatry'. He tells me (my translation from the Spanish):

That's spiritism! . . . we can consider it to be a 'revolution of new ideas'. Now, you will find people who will tell you 'I am a spiritist', and they're worshipping a 'Congo', an 'African' or an 'Indian' [spirit], you'll find a lot of people like that, who are spiritists and they're worshipping an image ... all that is mysticism! All that is lack of knowledge, because the spirit is infinite, the spirit is the astral, the spirit does not have a name, it has no race.

It is immediately striking that Durán's Marxism has, without doubt, not only politicized his spiritist philosophy but also influenced his conception 
of the legitimacy of the 'religious', and of course, its material culture. This may not be surprising when we consider some aspects of his biographical trajectory. From humble rural origins in the Oriente of Cuba, Durán openly admits to having gradually abandoned the kind of spiritist practices he grew up with since he was a child - espiritismo de cordón (Garcia Molina et al., 1998) - a particular kind of spiritism (found mostly in eastern provinces) whose African, indigenous and Catholic elements he now rejects as 'pious' and 'unscientific'. Espiritismo cientifico was, for him, a revelation; moreover, it was a spiritism he had to increasingly invest in once he was appointed leader of the Consejo Supremo by Cuba's new government during the first years of the Revolution. However, Durán has not abandoned his 'healing' practices altogether and this, as far as I could tell, was paradoxically what he was best known and admired for. While the Consejo holds Saturday study sessions, where passages of spiritist books are read and analysed, every weekday morning Durán often attends to long queues of people who come to consult him about their health problems, for advice or for massage. He also engages in reiki healing and strongly believes in the power of energia piramidal (pyramid energy) in his treatments, where a large wire structure in the shape of a pyramid is hung above the person in question. Rather than regarding such a structure in terms of 'matter', Durán's notion of the 'scientific' has instead been extended to encompass these activities, which are not seen as 'material' - morally or otherwise - but as progressive, modern, even medical. That the 'medical' idiom is a common frame among other cientificos more generally - where either allopathic or homeopathic forms of healing, or sometimes both, can be understood under the concept of 'medicine' by spiritists of various alignments - may be unsurprising given the moral prestige enjoyed by the medical sciences in Cuba, as a colleague of mine has recently suggested.

The Consejo is only one of a handful of successful espiritismo cientifico groups currently functioning in Havana. While Durán's revolutionary fervour may not be shared by all of these in the same way, his stance on what is 'material' and what is 'spiritual' is similar to those of the leaders of many of the other groups I had contact with. Ultimately, cientificos recognize that all mediums work with one and the same ontological stratum of beings: the difference between them is not one of cosmology, but of methodology. When answering the question of what spirisitism is for, the cientificos' discourse generates a series of oppositions - individual versus collective good, socialization versus materialization and anonymity versus the personalization of spirits. And these have become intrinsic to their efforts at successful boundary-work. Just as Engelke (2005) describes the African Masowe Apostolics' wariness of religious 'things', for these 'often betray the shortcomings of faith' (p. 121), we see clearly in both these ethnographic examples the precariousness of matter in the negotiation of a viable spirituality. But we are also led towards a more interesting 
if general observation that, like the Revolution, spiritists are not exempt from the contradictions of the so-called materialist or scientific ideals of modernity. The fact that many cientificos prefer to eliminate any 'religious' association from their practices, especially those of the Afro-Cuban kind, is indicative of the continued relevance of such categories as rationality and its opposite, superstition. This is true even if in Cuba, as Román (2007) has shown, Kardecist spiritists were never free of syncretism, just as the cruzados were not necessarily that 'African' in the first place (p. 34). To make so clear a distinction between these camps (as anthropologists) may thus be to reify what are complex historically and politically constructed differentiations, which themselves invite further examination.

\section{CONCLUDING REMARKS}

In this article, I have attempted to show that in the Afro-Cuban religious practices of santería and palo monte, and the various practices of spiritism, 'matter' is a densely moralized notion that effectively serves as the basis for the complex processes of intra- and inter-religious distinction that I have been calling 'boundary-work'. It may well be the case, as Miller (2005) states: 'that we cannot know who we are, or become what we are, except by looking in a material mirror' (p. 8). But that 'matter' itself, as Miller also argues, may be a mutable, plural and even relative category; or, rather, the fact that 'things' may not always be 'substanced' a priori, one way or another - a point succinctly made by Rowlands (2005) when he speaks of 'hierarchies of materiality' (p. 73) - is exactly what makes diverse ethnographic investigations of the concept interesting. Furthermore, the potentially transgressive nature of this notion is especially salient in religious contexts, where it is often through the friction of competing cosmologies and discourses that the borders of materiality and immateriality become visible at all. What I have tried to demonstrate is that there may be social and moral consequences, as well as ontological effects, from such boundaries. In my view, Cuba provides us with a provocative example of how moral agencies are achieved, objectified and contested via the production of spirits through matter and its repudiation. If one of the jobs of anthropology is to 'show how things that people make, make people' (Miller, 2005: 38), in Cuba the ethnographer need not extend his or her imagination too strenuously in an examination of how this is the case.

I have only briefly touched upon the importance of discourses of race and modernity in respect to the morality of materiality. Yet I agree with Wirtz's (2009) argument that in Cuba:

There is a fluid line between the objectification of people - as slaves, spirits of slaves, or suspect, marginalized black citizens - and the agency of objects (spiritually charged things, disease-bearing things) through which objectified subjects and agentive objects are mutually constituted. (p. 498) 
In this example, we are clearly not simply referring to 'matter out of place' (Douglas, 1966), but to the role of varying degrees or even densities of matter in the production of persons and things, as well as their corollary - certain forms of agency, and even consciousness. According to anthropologist Ochoa's main informant Isidra, for instance, palo monte is far more materialist than the Revolution: 'Cuban Socialism isn't materialist', she exclaimed. 'They're dreamers! Palo is materialist, it takes care of things here and now, with ingredients from the forest, from the earth!' (Ochoa, 2007: 483). It seems that, while competing notions of 'materialism' may be at stake in Cuban religious circles, we are also dealing with shared understandings of materiality and its capacity to create or annihilate existential possibilities, understandings which also resonate with certain Western models.

According to Rowlands (2005):

The materialist argument contains the intriguing suggestion that if selfrealization is a product of practical activity, then we will experience this as inequalities in a materiality of being. This is not so far from the general psychoanalytic point that consciousness expands in relation to others and to significant objects that exist independently both inside and outside the person. (p. 72)

Cuban ethnographers and historians have taken a variety of stances towards spiritist practices, many of which have been direct reflections of their socio-political environment, beginning with Fernando Ortiz himself (Ortiz,1924[1915]), who, as a prominent exponent of a particular social science of his time, saw with undeniable admiration a version of his own analytical positivism latent in a 'scientific' espiritismo that was intended to be anything but religious. Questions of science and progress and the place of religious 'matter' have also been deeply contentious in a post-Revolution Cuba that has struggled to define its stance towards the 'immaterial' (so much so that in the early days there were attempts to instil the Revolution with what could be understood as an 'esoteric' form of materialism, see Aguero, 1961). It is perhaps not entirely remarkable that the previously mentioned Consejo Supremo, as opposed to other Afro-Cuban religious or cruzado temples or houses, was somehow integrated into the Revolutionary process. Spiritism has historically been both more ambiguous and less threatening than other modes of religiosity precisely because of its appeal to 'European-derived' scientific thought. But, as a final thought, as Palmié has suggested (personal communication, 2009), one of the ironies of the convergence of espiritismo cientifico with contemporary Cuban socialism (and socialist speak, as evident in Durán's own practice) is that the 'materialization' of what, among cientificos (and others) is referred to as 'lo espiritual', may actually have its equivalent in Marx's own reinterpretation of Hegelian idealism. If, Palmié contends, Marx remained an unsuspecting proponent of the 'spiritualization' of 
matter (rather than just the 'materialization' of the spirit), then perhaps the Marxist-Leninism that was set in motion 50 years ago in Cuba was less a 'scientific' Marxism and more an 'enchanted' science. Here again, another kind of boundary-work may prevail.

\section{Acknowledgments}

This article is based on 16 months of doctoral fieldwork in the city of Havana, Cuba, funded by the Economic and Social Research Council and the Royal Anthropological Institute. I am grateful to Jesus, Arturo, Montalbo and, especially, Alfredo Durán Arias, for his warmth and generosity. I also thank Stephan Palmié and one other anonymous reviewer for their excellent comments and suggestions on this text.

\section{Notes}

1. This refers to Allan Kardec, the assumed name of Hyppolite Léon Denizard Rivail (1804-69), French teacher and educator who developed the tenets of scientific spiritism.

\section{References}

Agüero, Sixto Gaston (1961) El materialismo explica el espiritismo y la santería. Havana: Ediciónes Orbe.

Argyriadis, Kali (2005) 'El desarrollo del turismo religioso en la Habana y la acusación de mercantilismo', Desacatos 18: 29-52.

Ayorinde, Christine (2004) Afro-Cuban Religiosity, Revolution and National Identity. Gainsville: University Press of Florida.

Bolivar, Natalia (1990) Los Orichas en Cuba. Havana: Ediciones Union.

Bolivar, Natalia and Diaz de Villegas, Carmen Gonzalez (1998) Ta makuende yaya y las relgas de Palo Monte: mayombe, brillumba, kimbisa, shamalongo. Havana: Ediciones Union.

Bolivar, Natalia and Orozco, Roman (1998) Cuba Santa: Comunistas, Santeros y Cristianos en la Isla de Fidel Castro. Madrid: Editorial El Pais.

Brandon, George (1997[1993]) Santería from Africa to the New World: The Dead Sell Memories. Bloomington: Indiana University Press.

Bronfman, Alejandra (2004) Measures of Equality: Social Science, Citizenship and Race in Cuba, 1902-1940. Chapel Hill: University of North Carolina Press.

Brown, Diana De G. (1986) Umbanda Religion and Politics in Urban Brazil. Ann Arbor: UMI Research Press.

Brown, David H. (2003) Santería Enthroned: Art, Ritual, and Innovation in an AfroCuban Religion. Chicago: University of Chicago Press.

Castellanos, Jorge and Castellanos, Isabel (1992) Cultura Afrocubana 3, Las Religiones y las Lenguas. Miami: Ediciones Universal.

Douglas, Mary (1966) Purity and Danger: An Analysis of the Concepts of Pollution and Taboo. London: Routledge \& Kegan Paul

Durán Arias, Alfredo (c. 2006) 'El Espiritismo en la Vision de Alfredo Durán Arias', leaflet printed by the Consejo Supremo Nacional Espiristista de Cuba.

Engelke, Matthew (2005) 'Sticky Subjects and Sticky Objects: The Substance of African Christian Healing', in D. Miller (ed.) Materiality, pp. 118-39. Durham, NC: Duke University Press. 
Engelke, Matthew (2007) A Problem of Presence: Beyond Scripture in an African Church. Berkeley: University of California Press.

Figarola, Joel James (2006) La Brujeria Cubana: El Palo Monte, Aproximación al Pensamiento Abstracto de la Cubania. Santiago de Cuba: Editorial Oriente.

Fuentes Guerra, Jesús and Gómez, Grisel (1996) Cultos Afrocubanos: Un estudio etnolinguistico. Havana: Editorial Ciencias Sociales.

Garcia Molina, José Antonio, Garrido Mazorra, Maria Mercedes and Gutierrez, Daisy Frainas (1998) Huellas vivas del Indocubano. Toronto: Lugus Libros.

Gieryn, Thomas F. (1983) 'Boundary-Work and the Demarcation of Science from Non-Science: Strains and Interests in Professional Ideologies of Scientists', American Sociological Review 48(6): 781-95.

Hagedorn, Katherine J. (2001) Divine Utterances: The Performance of Afro-Cuban Santería. Washington: Smithsonian Institution Press.

Hess, David J. (1991) Spirits and Scientists: Ideology, Spiritism and Brazilian Culture. University Park: Pennsylvania State University Press.

Hess, David J. (1994) Samba in the Night: Spiritism in Brazil. New York: Columbia University Press.

Lachatañaré, Romulo (2001) El Sistema Religioso de los Afrocubanos. Havana: Editorial de Ciencias Sociales.

Miller, Daniel (2005) 'Materiality: An Introduction', in D. Miller (ed.) Materiality. Durham, NC: Duke University Press.

Ochoa, Todd Ramon (2007) 'Versions of the Dead: Kalunga, Cuban-Kongo Materiality, and Ethnography', Cultural Anthropology 22(4): 473-500.

Ortiz, Fernando, (1924[1915]) 'La Filosofia Penal de los Espiritistas', Estudio de Filosofia Juridica, 4th edn. Madrid: Editorial Reus.

Ortiz, Fernando (1995[1906]) Los Negros Brujos. Havana: Editorial de Ciencias Sociales.

Palmié, Stephan (2002) Wizards and Scientists: Explorations in Afro-Cuban Modernity and Tradition. Durham, NC: Duke University Press.

Román, Reinaldo L. (2007) Governing Spirits: Religion, Miracles, and Spectacles in Cuba and Puerto Rico, 1898-1956. Chapel Hill: University of North Carolina Press.

Rowlands, Michael (2005) 'A Materialist Approach to Materiality', in D. Miller (ed.) Materiality, pp. 72-87. Durham, NC: Duke University Press.

Taussig, Michael (1993) Mimesis and Alterity: A Particular History of the Senses. London: Routledge

Wirtz, Kristina (2009) 'Hazardous Waste: The Semiotics of Ritual Hygiene in Cuban Popular Religion', Journal of the Royal Anthropological Institute 15: 476-501

- Diana ESPIRito SANTo is a Postdoctoral Researcher in Social Anthropology at the Institute of Social Sciences (ICS), University of Lisbon, as well as Visiting Researcher at the Museu Nacional, Federal University of Rio de Janeiro. She wrote her $\mathrm{PhD}$ at University College London on concepts of personhood, knowledge and mediumship in Cuban forms of spiritism, and on the role of the dead in Afro-Cuban religion. Her current project focuses on learning in the Brazilian practices of Umbanda, and on the use of situated, embodied and ecological approaches to cognition in the anthropology of religion. Address: Instituto de Ciencias Sociais da Universidade de Lisboa, Avenida Professor Aníbal de Bettencourt 9, 1600-189 Lisbon, Portugal. [email: gimmefish@yahoo.com] 